Pesq. Vet. Bras. 36(11):1067-1074, novembro 2016 DOI: 10.1590/S0100-736X2016001100002

\title{
Safety and immunogenicity of a glycoprotein E gene-deleted bovine herpesvirus 1 strain as a candidate vaccine strain $^{1}$
}

\author{
Marcelo Weiss $^{3}$, Deniz Anziliero ${ }^{4}$, Mathias Martins ${ }^{2}$, Rudi Weiblen ${ }^{2}$ \\ and Eduardo Furtado Flores ${ }^{2 *}$
}

\begin{abstract}
Weiss M., Anziliero D., Martins M., Weiblen R. \& Flores E.F. 2016. Safety and immunogenicity of a glycoprotein $E$ gene-deleted bovine herpesvirus 1 strain as a candidate vaccine strain. Pesquisa Veterinária Brasileira 36(11):1067-1074. Setor de Virologia, Departamento de Medicina Veterinária Preventiva, Universidade Federal de Santa Maria, Av. Roraima 1000, Santa Maria, RS 97105-900, Brazil. E-mail: eduardofurtadoflores@gmail.com

A glycoprotein E-deleted Brazilian bovine herpesvirus 1 (BoHV-1gE $\Delta$ ) was tested regarding to safety and immunogenicity. Intramuscular inoculation of young calves with a high virus dose did not result in clinical signs or virus shedding during acute infection or after dexamethasone administration. Calves vaccinated once IM (group I) or subcutaneously (group II) with live BoHV-1gE $\Delta$ or twice with inactivated virus plus aluminum hydroxide (group IV) or Montanide $^{\mathrm{TM}}$ (group V) developed VN titers of 2 to 8 (GMT:2); 2 to 4 (GMT:1.65); 2 to 16 (GMT:2.45) and 2 to 128 (GMT:3.9), respectively. All BoHV-1gE $\Delta$ vaccinated calves remained negative in an anti-gE ELISA. Lastly, six young calves vaccinated with live BoHV-1gE $\Delta$ and subsequently challenged with a virulent BoHV-1 strain shed less virus and developed only mild and transient nasal signs comparing to unvaccinated calves. Thus, the recombinant BoHV-1gE $\Delta$ is safe and immunogenic for calves and allows for serological differentiation by a gE-ELISA test.
\end{abstract}

INDEX TERMS: BoHV-1, cattle, marker vaccine, differential vaccine.

RESUMO.- [Atenuação e imunogenicidade de uma cepa recombinante do herpesvírus bovino tipo 1 defectiva na glicoproteína E.] Um isolado brasileiro de herpesvírus bovino tipo 1, contendo uma deleção na glicoproteína $\mathrm{E}$ (gE - BoHV-1gE $\Delta$ ) foi submetido a testes para avaliar a sua segurança e imunogenicidade em bovinos. Bezerros foram submetidos à inoculação intramuscular com uma alta dose viral e não demonstraram sinais clínicos ou excreção viral durante a fase aguda ou após tentativa de reativação viral pela administração de dexametasona. Bezerros que receberam uma dose do vírus vivo, contendo a deleção na gE, pela via intramuscular (grupo I) ou pela via subcutânea (grupo II) ou duas doses do vírus inativado utilizando o adjuvante hidróxido de alumínio (grupo IV) ou Montanide ${ }^{\mathrm{TM}}$

\footnotetext{
${ }^{1}$ Received on January 19, 2016.

Accepted for publication on July 28, 2016.

${ }^{2}$ Setor de Virologia, Departamento de Medicina Veterinária Preventiva, Universidade Federal de Santa Maria (UFSM), Av. Roraima 1000, prédio 63a , Santa Maria, RS 97105-900, Brazil. *Corresponding author: eduardofurtadoflores@gmail.com

${ }^{3}$ Universidade do Oeste de Santa Catarina (Unoesc), Rua Dirceu Giordani 696, Xanxerê, SC 89820-000, Brazil.

${ }^{4}$ Faculdade Meridional (Imed), Rua Senador Pinheiro 304. Passo Fundo, RS 99070-220, Brazil.
}

(grupo V), desenvolveram títulos de anticorpos neutralizantes de 2 a 8 (GMT: 2); 2 a 4 (GMT: 1,65); 2 a 16 (GMT: 2,25 ) e de 2 a 128 (GMT: 3,9), respectivamente. Todos os bezerros vacinados se mantiveram soronegativos quando utilizado um kit ELISA específico para a gE. Para o teste de segurança, seis bezerros foram vacinados com o vírus vivo BoHV-1gE $\Delta$, sendo estes posteriormente desafiados com uma cepa virulenta de BoHV-1. Estes bezerros excretaram menos vírus e desenvolveram apenas sinais clínicos moderados e transitórios quando comparados com dados coletados de quatro animais não-vacinados. Com base nestes resultados, podemos confirmar que o vírus do BoHV-1 que contém a deleção na gE (BoHV-1gE $\Delta$ ) é seguro e suficientemente imunogênico para bezerros e permite a diferenciação sorológica entre os animais vacinados e infectados perante a a um teste ELISA commercial específico para a gE.

TERMOS DE INDEXAÇÃO: BoHV-1, bovinos, vacinas marcadas, vacinas diferenciais.

\section{INTRODUCTION}

Bovine herpesvirus 1 (BoHV-1) is associated with a variety of clinical manifestations in cattle, including respiratory disease (infectious bovine rhinotracheitis - IBR), genital 
disorders (infectious pustular vulvovaginitis - IPV or infectious pustular balanoposthitis - IPB), transient infertility and abortions (Kahrs 2001). BoHV-1 is an enveloped DNA virus belonging to the family Herpesviridae, subfamily Alphaherpesvirinae, genus Varicellovirus (Muylkens et al. 2007). As other alphaherpesviruses, BoHV-1 establishes lifelong latent infection in sensory nerve ganglia after acute infection, from which it can be periodically reactivated and transmitted (Roizmann et al. 1992).

Vaccination has been largely used to prevent and reduce the losses associated with BoHV-1 infection, but traditional vaccines usually contain live attenuated or whole inactivated virus and induce a serological response undistinguishable from that induced by natural infection (Van Drunen Littel-Van den Hurk 2006). In this regard, gene-deleted vaccines that allow serological differentiation - also called DIVA vaccines (differentiating infected from vaccinated animals) - have proven to be attractive alternatives for traditional vaccines (Kaashoek et al. 1994). The envelope glycoprotein E (gE) has been the choice target for deletion towards the production of antigenically marked vaccines for several alphaherpesviruses, including BoHV-1 (Kaashoek et al. 1994, 1995, Chowdhury et al. 1999), BoHV-5 (Brum et al. 2010a,b) and swine herpesvirus 1 or Aujeszky disease virus (Moormann et al. 1990, Van Oirschot et al. 1990).

Several efforts have been made to produce and to make commercially available BoHV-1 marker vaccines in Brazil (Franco et al. 2002a, 2002b, Spilki et al. 2005). A gE-negative BoHV-1 strain has been constructed and evaluated regarding to safety, immunogenicity and potential serological differentiation (Spilki et al. 2005, Weiss et al. 2010). A gE and thymidine kinase (TK) double deletion BoHV-5 recombinant strain was constructed and proposed as a candidate vaccine strain (Brum et al. 2010b). Nonetheless, no BoHV-1 or BoHV-5 marker vaccine is currently available in Brazilian market. To fill this gap, we constructed a gE-deleted strain (BoHV-1gE $\Delta$ ) out of a well characterized genital Brazilian BoHV-1 strain, intended to be used as a vaccine strain (Weiss et al. 2015).

This article reports an investigation on the safety and immunogenicity of the recombinant BoHV-1gE $\Delta$ in calves and on its ability to confer protective immunity against challenge with a heterologous BoHV-1 strain.

\section{Viruses and cells}

\section{MATERIALS AND METHODS}

The recombinant BoHV-1gE $\Delta$ was constructed out of a Brazilian BoHV-1 SV56/90 strain (Weiblen et al. 1992). All procedures of construction and in vitro characterization of the recombinant were published recently (Weiss et al. 2015). The experiments described herein used the clone \#3, passage \# 3 of the recombinant BoHV-1gE $\Delta$. The BoHV-1 strain EVI123 was used in the challenge experiment (virus kindly provided by Dr. Paulo Michel Roehe, Universidade Federal do Rio Grande do Sul, Brazil). Madin Darby bovine kidney cells (MDBK, ATCC - CCL-22) maintained in MEM (Eagle's Minimum Essential Medium, HiMedia Laboratories, India), supplemented with $10 \%$ inactivated and $\gamma$-irradiated fetal bovine serum (Nutricell, Brazil), $100 \mathrm{U} / \mathrm{mL}$ of penicillin and $100 \mu \mathrm{g} / \mathrm{mL}$ of streptomycin (Invitrogen, USA) were used in all procedures.

\section{Animals, virological and serological monitoring}

All experiments used calves free of BoHV-1 antibodies, as ascertained by two negative VN assays 30 days apart (Weiss et al. 2015). The breed and age of the animals varied according to the experiment (safety, immunogenicity and vaccination-challenge) and are specified in the respective sections. Animals were maintained in native grass and/or supplemented with alfalfa and given water ad libitum.

Nasal swabs were collected and processed for virus isolation in MDBK cells as described previously (Anziliero et al. 2011) and positive samples were quantitated by limiting dilution and virus titers were expressed as $\mathrm{TCID}_{50} / \mathrm{mL}$. Serum samples obtained at different times after virus inoculation or immunization were tested for virus neutralizing (VN) antibodies against BoHV-1 by virus neutralization assay, using the parental virus as the challenge virus (Weiss et al. 2010). Titers were expressed as the reciprocal of the highest dilution that prevented virus replication, were transformed in geometric mean titers (GMT - $\log _{2}$ ) for the calculation of the mean antibody titers of each group (Thrusfield 1986). Anti-gE antibodies in sera of inoculated-vaccinated calves were tested using a commercial anti-gE antibody ELISA test according to instructions (Bovine Rhinotracheitis Virus gE Antibody Test - IDEXX - the Netherlands).

All procedures of animal handling and experimentation were conducted under veterinary supervision and according to recommendations by the Brazilian Committee of Animal Experimentation (COBEA, law \#6.638 of May, 8th, 1979). The experiment was approved by an Institutional Animal Ethics Committee (UFSM, approval \# 34/2014).

\section{Safety test}

Five 3 to 4-months-old Holstein calves, seronegative to BoHV1 , were inoculated by the intramuscular route (IM) with the recombinant BoHV-1gE $\Delta$ in a dose of $10^{8.5} \mathrm{TCID}_{50}$ per animal. Two calves were kept in contact with the inoculated animals. Inoculated and sentinel animals were monitored in a daily basis (clinical signs, body temperature) and submitted to collection of nasal swabs up to day 14 post-inoculation (pi). At day 42pi, inoculated and sentinel animals were submitted to dexamethasone administration (Dx, Decadronal, Achê, Brazil, 0.1mg.kg.day during 5 days) and monitored for virus shedding and clinical signs up to day 14 post-Dx.

\section{Immunogenicity tests}

The immunogenicity tests were performed in 8 to 10 -monthsold cross-breed calves maintained in extensive conditions on natural grass. The immunogenicity of BoHV-1gE $\Delta$ was evaluated both as a live virus and in an inactivated vaccine preparation. In the first, 17 calves were inoculated IM (group I, $n=8$ ) or SC (group II, $\mathrm{n}=9$ ) with $10^{7.3} \mathrm{TCID}_{50}$ of viable BoHV-1gE $\Delta$. As controls, three calves were inoculated IM with the parental virus (SV56/90 strain - group III). Sera collected at the day of vaccination (day zero) and at day 42 post-vaccination (pv) were tested for VN and gE antibodies.

In the second test, a BoHV-1gE $\Delta$ virus stock was inactivated with binary ethylenimine according to standard protocols (Brum et al. 2010a). Then, two vaccine formulations were prepared, either using $15 \%$ of aluminum hydroxide (Omega, Brazil - group IV) or $50 \%$ of Montanide ${ }^{\mathrm{TM}}$ gel 1 (high molecular weight polyacrylic polymer - Seppic, USA - group V), both in an aqueous formulation. Each viral dose contained inactivated virus correspondent to $10^{7.3} \mathrm{TCID}_{50}$ before inactivation in a final volume of $5 \mathrm{~mL}$. Calves were immunized IM twice (30 days apart) and serum for VN tests and ELISA was collected at day $30 \mathrm{pv}$ and 30 days later (day $60 \mathrm{pv}$ ). 


\section{Vaccination-challenge experiments}

This experiment used 3 to 4-months-old Holstein calves, seronegative to BoHV-1. Six calves were vaccinated IM with BoHV$1 \mathrm{gE} \Delta$ in a dose of $10^{7.5} \mathrm{TCID}_{50}$ and four were kept as non-vaccinated controls. Forty-seven days pv, vaccinated and controls were challenged by IN instillation of a highly virulent BoHV-1 strain - EVI123 - [20] in a dose of $10^{7.5} \mathrm{TCID}_{50}$ per animal, following by swabbing the inocullum against the nasal mucosa. Clinical signs, body temperature and nasal swabs for virus isolation and quantitation were collected in a daily basis for 14 days. Blood for serology (VN and gE-ELISA) was obtained at the day of vaccination, at the day of challenge ( 47 days pv) and 14 days after challenge. The clinical monitoring consisted of daily clinical examination by two veterinarians who were not aware of the experimental groups, who attributed scores to the following parameters for each animal/day: nasal secretion $(0=$ absence to $4=$ abundant, mucopurulent); ocular secretion ( $0=$ absence or $1=$ presence); dyspnea $(0=$ absence or $1=$ presence $)$; conjunctivitis $(0=$ absence or $1=$ presence); nasal signs $(0=$ normal nasal mucosa to $6=$ generalized pustules). The clinical scores were adapted from a previous paper (Anziliero 2011).

\section{Statistical analysis}

The results shown in the text, tables and figures are expressed as the mean standard error (SEM). Differences among the treatments were tested by Student's t-test in one way analysis of variance (ANOVA), using the Assistat program, version 7.7. The least significance difference between groups for $\mathrm{p}<0.05$ was calculated to determine whether treatments were statistically different.

\section{RESULTS}

\section{Safety of the recombinant BoHV-1gE $\Delta$ in calves}

Even using such a high virus dose, correspondent to 10to 100 -times the highest commercial vaccine dose, none of the inoculated animals showed any clinical sign suggestive of BoHV-1 infection. Inoculated animals remained healthy and with normal temperature throughout the monitoring period (Table 1). Likewise, no infectious virus was recovered from nasal swabs collected daily following virus inoculation. In addition, the sentinel in-contact calves remained healthy, nasal swabs were negative for virus and the animals remained seronegative, demonstrating lack of trans- mission of the vaccine virus. To confirm efficient replication of the vaccine virus, all vaccinated animals developed VN antibodies on day 42pi (4-16, GMT: 2.6). As expected, these calves remained negative for gE antibodies (Table 1).

To investigate whether the vaccine virus would reactivate latent infection, vaccinated animals were submitted to Dx treatment at day 42pi and monitored for virus shedding and VN antibodies. Again, none of the vaccinated animals showed clinical signs of BoHV-1 infection, shed virus in nasal secretions or had an increase in VN titers, indicating lack of reactivation. Taken together, these results showed that the recombinant BoHV-1gE $\Delta$ is safe for calves after IM administration - even using an excessively high virus titer - and is not excreted in nasal secretions during acute replication or after Dx administration.

\section{Immunogenicity of the recombinant BoHV-1gE $\Delta$ in calves}

The immunogenicity of the recombinant BoHV-1gE $\Delta$ was evaluated in beef calves (8 to 10-months-old) under field conditions, testing either a live virus vaccine (one dose) or an inactivated, adjuvanted vaccine preparation (two doses). Serological tests (VN and anti-gE ELISA) were performed in sera collected day 42pv (live virus) or after the second vaccine administration, at day $60 \mathrm{pv}$ (inactivated preparation). Calves immunized with live virus IM (group I) developed VN titers of 2-8 (GMT: 2), whereas calves immunized with live virus SC (group II) or the group immunized with the parental vírus (group III) developed VN titers of 2-4 (GMT: 1.65). Both groups (group I and II) remained negative for $\mathrm{gE}$ antibodies at day $42 \mathrm{pv}$ and the three control calves inoculated with the parental virus developed gE antibodies (Table 2). These results showed that calves immunized with live recombinant virus developed VN titers comparable to those developed by calves immunized with wild type virus, yet remained negative for $\mathrm{gE}$ antibodies.

All calves immunized with inactivated virus, regardless the adjuvant, developed VN titers and remained negative for gE antibodies at day 30 post-revaccination (Table 3). Calves of group V (adjuvant Montanide ${ }^{\mathrm{TM}}$ gel 1) developed

Table 1. Results of the safety test. Clinical, virological and serological findings in calves inoculated intramuscularly with the recombinant BoHV-1gE $\Delta$ and monitored during the acute phase and after dexamethasone (Dx) administration

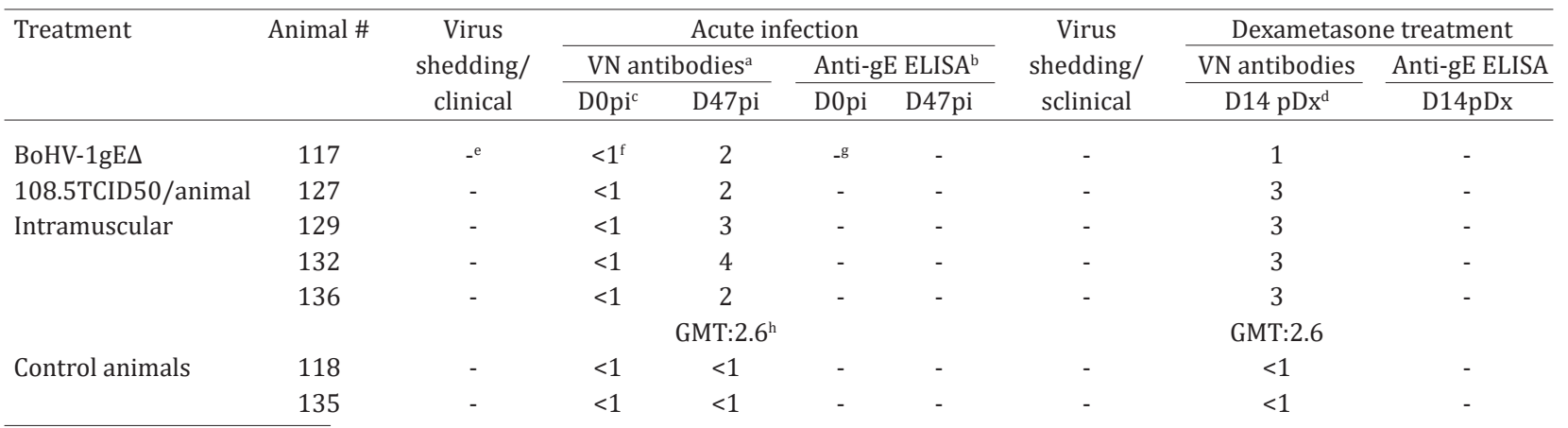

${ }^{\text {a } V i r u s ~ n e u t r a l i z i n g ~ a n t i b o d i e s ~ w e r e ~ m e a s u r e d ~ b y ~ v i r u s ~ n e u t r a l i z a t i o n ~ a s s a y ~ a s ~ d e s c r i b e d ~ i n ~ m a t e r i a l ~ a n d ~ m e t h o d s ; ~}{ }^{\text {b }}$ Sera submitted to a commercial anti-gE antibody ELISA test (Bovine Rhinotracheitis Virus gE Antibody Test (IDEXX) the Netherlands); ${ }^{\mathrm{c}}$ pi - post-inoculation; ${ }^{\mathrm{d}}$ pDx = post-dexamethasone; ${ }^{\mathrm{e}}$ No clinical signs or virus shedding; ${ }^{\mathrm{f}}$ Sample negative in VN assay at its lower dilution (1:2); ${ }^{\mathrm{g}}$ Samples negative in the anti-gE ELISA test; ${ }^{\mathrm{h}}$ The average of serology results is expressed as geometric mean titers (GMT - $\log _{2}$ ). 
Table 2. Results of the immunogenicity test using live virus. Serological response of calves vaccinated with live recombinant BoHV-1gE $\Delta$ and tested for virus neutralizing and gE antibodies at day 42 post-vaccination

\begin{tabular}{|c|c|c|c|c|}
\hline \multirow[t]{2}{*}{ Treatment } & \multirow[t]{2}{*}{ Animal \# } & \multicolumn{2}{|c|}{ VN antibodies ${ }^{a}$} & \multirow{2}{*}{$\frac{\text { Anti-gE antibodies }}{\text { Day } 42 p v}$} \\
\hline & & Day 0 & Day $42 \mathrm{pv}^{\mathrm{c}}$ & \\
\hline Group I & 101 & $<1^{\mathrm{d}}$ & 3 & - e \\
\hline BoHV-1gE $\Delta$ & 102 & $<1$ & 3 & - \\
\hline $10^{7.3} \mathrm{TCID}_{50} /$ animal & 104 & $<1$ & 1 & - \\
\hline \multirow[t]{6}{*}{ Intramuscular } & 105 & $<1$ & 2 & - \\
\hline & 106 & $<1$ & 2 & - \\
\hline & 107 & $<1$ & 3 & - \\
\hline & 108 & $<1$ & 1 & - \\
\hline & 109 & $<1$ & 1 & - \\
\hline & & & GMT: $2 \mathrm{a}^{\mathrm{f}}$ & \\
\hline Group II & 5 & $<1$ & 2 & - \\
\hline BoHV-1gE $\Delta$ & 76 & $<1$ & 2 & - \\
\hline $10^{7.3} \mathrm{TCID}_{50} /$ animal & 89 & $<1$ & 1 & - \\
\hline \multirow[t]{7}{*}{ Subcutaneous } & 99 & $<1$ & 2 & - \\
\hline & 152 & $<1$ & 1 & - \\
\hline & 154 & $<1$ & 2 & - \\
\hline & 157 & $<1$ & 2 & - \\
\hline & 158 & $<1$ & 1 & - \\
\hline & 166 & $<1$ & 2 & - \\
\hline & & & GMT: $1.65 \mathrm{a}$ & \\
\hline Group III & 112 & $<1$ & 1 & $+g$ \\
\hline BoHV-1 SV56/90 & 113 & $<1$ & 2 & + \\
\hline $10^{7.3} \mathrm{TCID}_{50} /$ animal & 114 & $<1$ & 2 & + \\
\hline Intramuscular & & & GMT: $1.65 \mathrm{a}^{\mathrm{h}}$ & \\
\hline
\end{tabular}

a Virus neutralizing antibodies measured by virus neutralization assay as described in material and methods; ${ }^{\text {b }}$ Sera submitted to a commercial anti-gE antibody ELISA test (Bovine Rhinotracheitis Virus gE Antibody Test (IDEXX) the Netherlands); ${ }^{\mathrm{c}} \mathrm{pv}=$ post-vaccination. ${ }^{\mathrm{d}}$ Sample negative in VN assay at its lower dilution (1:2); ${ }^{e}$ Samples negative in the anti-gE ELISA test; ${ }^{\mathrm{f}}$ The average of serology results is expressed as geometric mean titers (GMT - log2); ${ }^{g}$ Sample positive in the anti-gE ELISA test; ${ }^{\mathrm{h}}$ GMT from groups are statistically similar.

higher titers (2 to 128, GMT: 3.9) than those of group IV (aluminum hydroxide, VN titers 2 to 16, GMT: 2.45). Both groups remained negative for gE antibodies after the two vaccine doses (Table 3). These results demonstrate that the inactivated vaccine preparation was immunogenic for calves and produced an immune response that could be differentiated from that induced by wild type BoHV-1 by the use of a commercial anti-gE ELISA kit.

\section{Protection conferred by the recombinant BoHV-1gE $\Delta$}

The protection conferred by vaccination with the recombinant BoHV-1gE $\Delta$ was evaluated in 3 to 4-months-old Holstein calves, challenged IN with a highly virulent BoHV1 at day $47 \mathrm{pv}$. The body temperature of vaccinated calves remained within normal limits up to day 6 post-challenge (pc), in contrast with the controls, which presented an increase in temperature (Fig.1). From day 7pc to the end of monitoring, both groups presented a drop in body temperature, accompanying a drastic drop in ambient temperature (not shown). Regardless, the temperatures of vaccinated animals remained generally below the temperature of controls.

The duration of virus shedding was significantly reduced $(\mathrm{p}<0.05)$ in vaccinated animals (6.8 days \pm 2.4 days),
Table 3. Results of the immunogenicity test using inactivated virus. Serological response of calves vaccinated twice with inactivated, adjuvanted BoHV-1gE $\Delta$ and tested for virus neutralizing and $\mathrm{gE}$ antibodies at day 60 post-vaccination (30 days after the second vaccine dose)

\begin{tabular}{|c|c|c|c|c|}
\hline \multirow[t]{2}{*}{ Treatment } & \multirow[t]{2}{*}{ Animal \# } & \multicolumn{2}{|c|}{ VN titers ${ }^{\mathrm{a}}$} & \multirow{2}{*}{$\frac{\text { Anti-gE antibodies }^{\mathrm{b}}}{\text { Day } 60 \mathrm{pv}}$} \\
\hline & & Day 0 & Day $60^{c} \mathrm{pv}^{\mathrm{d}}$ & \\
\hline Group IV & 2 & $<1^{\mathrm{e}}$ & 2 & $-f^{f}$ \\
\hline BoHV-1gE $\Delta$ & 30 & $<1$ & 2 & - \\
\hline $10^{7.3} \mathrm{TCID}_{50} /$ animal & 50 & $<1$ & 1 & - \\
\hline \multirow[t]{2}{*}{ Subcutaneous } & 54 & $<1$ & 2 & - \\
\hline & 71 & $<1$ & 2 & - \\
\hline Adjuvant: & 74 & $<1$ & 2 & - \\
\hline \multirow[t]{2}{*}{ Aluminum hydroxide } & 87 & $<1$ & 3 & - \\
\hline & 95 & $<1$ & 3 & - \\
\hline Two vaccine doses & 96 & $<1$ & 3 & - \\
\hline \multirow[t]{5}{*}{ at 30 days interval } & 98 & $<1$ & 4 & - \\
\hline & 119 & $<1$ & 3 & - \\
\hline & 121 & $<1$ & 3 & - \\
\hline & 125 & $<1$ & 2 & - \\
\hline & & & GMT: $2.45 \mathrm{a}^{\mathrm{g}}$ & \\
\hline Group V & 1 & $<1$ & 4 & - \\
\hline BoHV-1gE $\Delta$ & 3 & $<1$ & 3 & - \\
\hline $10^{7.3} \mathrm{TCID}_{50} /$ animal & 8 & $<1$ & 4 & - \\
\hline \multirow[t]{2}{*}{ Subcutaneous } & 9 & $<1$ & 4 & - \\
\hline & 11 & $<1$ & 4 & - \\
\hline Adjuvant: & 22 & $<1$ & 3 & - \\
\hline \multirow{2}{*}{ Montanide ${ }^{\mathrm{TM}}$ Gel 1} & 35 & $<1$ & 2 & - \\
\hline & 58 & $<1$ & 5 & - \\
\hline Two vaccine doses & 61 & $<1$ & 7 & - \\
\hline \multirow[t]{5}{*}{ at 30 days interval } & 62 & $<1$ & 4 & - \\
\hline & 78 & $<1$ & 1 & - \\
\hline & 85 & $<1$ & 5 & - \\
\hline & 88 & $<1$ & 5 & - \\
\hline & 120 & $<1$ & $\begin{array}{c}4 \\
\text { GMT: } 3.9^{\mathrm{b}}\end{array}$ & - \\
\hline
\end{tabular}

a Virus neutralizing antibodies measured by virus neutralization assay as described in material and methods; ${ }^{b}$ Sera submitted to a commercial anti-gE antibody ELISA test (Bovine Rhinotracheitis Virus gE Antibody Test - IDEXX - the Netherlands); ${ }^{\mathrm{c}} 30$ days after the second vaccine dose; ${ }^{\mathrm{d}} \mathrm{pv}$ - post-vaccination; ${ }^{\mathrm{e}}$ Sample negative in VN assay at its lower dilution (1:2); ${ }^{\mathrm{f}}$ Samples negative in the anti-gE ELISA test; $\mathrm{g}$ The average of serology results is expressed as geometric mean titers (GMT - $\log 2$ ).

comparing with controls ( 11 days \pm 2.6 days). Virus shedding was no longer detected after day $9 \mathrm{pc}$ in vaccinated animals whereas it continued up to day $13 \mathrm{pc}$ in the controls. The differences in virus titers in nasal secretions (controls versus vaccinated) were $3 \log _{10}$ ( 3 days); $2 \log _{10}$ ( 3 days); 1 $\log _{10}$ (3 days) whereas in three days there was no difference (Fig.2).

The vaccinated animals presented milder and transient clinical signs comparing to the control group. The main differences concerned to the amount and aspect of nasal discharge, presence of ocular discharge and conjunctivitis, and lesions (vesicles, pustules, fibrinous membrane) in the nasal mucosa. The animals from the control group presented higher amount of nasal discharge and the secretion evolved to mucopurulent in 3 out of 4 animals. These animals also presented serous ocular discharge and conjunctivitis in five of the 14 days of monitoring; in addition to higher number 
Table 4. Serological response of calves immunized with the recombinant BoHV-1gE $\Delta$ and challenged intranasally with a heterologous, virulent BoHV-1 strain at day 47 post-vaccination

\begin{tabular}{|c|c|c|c|c|c|c|c|c|c|}
\hline \multirow[t]{3}{*}{ Treatment } & \multirow[t]{3}{*}{ Animal \# } & \multicolumn{4}{|c|}{ Post-vaccination (pv) } & \multicolumn{4}{|c|}{ Post-challenge (pc) } \\
\hline & & \multicolumn{2}{|c|}{ VN titer $^{\mathrm{a}}$} & \multicolumn{2}{|c|}{ Anti-gE antibodies ${ }^{b}$} & \multicolumn{2}{|c|}{ VN titer } & \multicolumn{2}{|c|}{ Anti-gE antibodies } \\
\hline & & D0 & $\mathrm{D} 47 \mathrm{pv}$ & D0 & $\mathrm{D} 47 \mathrm{pv}$ & D30pc & D90pc & D30pc & D90pc \\
\hline Immunized & 109 & $<1^{c}$ & 2 & $-{ }^{d}$ & - & 4 & 2 & $+^{e}$ & + \\
\hline BoHV-1gE $\Delta$ & 130 & $<1$ & 2 & - & - & 6 & 3 & + & + \\
\hline $10^{7.5} \mathrm{TCID}_{50} /$ animal & 131 & $<1$ & 3 & - & - & 7 & 4 & + & + \\
\hline \multirow[t]{4}{*}{ Intramuscular } & 134 & $<1$ & 2 & - & - & 5 & 3 & + & + \\
\hline & 139 & $<1$ & 2 & - & - & 4 & 1 & + & + \\
\hline & 142 & $<1$ & 1 & - & - & 7 & 5 & + & + \\
\hline & & & GMT: $2^{\mathrm{f}}$ & & & GMT: 5.5 .2 & GMT: 3 & & \\
\hline \multirow[t]{4}{*}{ Control animals } & 01 & $<1$ & $<1$ & - & - & 2 & 5 & + & + \\
\hline & 03 & $<1$ & $<1$ & - & - & 1 & 2 & + & + \\
\hline & 108 & $<1$ & $<1$ & - & - & 3 & 2 & + & + \\
\hline & 105 & $<1$ & $<2$ & - & - & $\begin{array}{c}2 \\
\text { CMT. }\end{array}$ & $\begin{array}{c}5 \\
\text { CMT. } 35\end{array}$ & + & + \\
\hline
\end{tabular}

\footnotetext{
${ }^{a}$ Virus neutralizing antibodies measured by virus neutralization assay as described in material and methods; ${ }^{\mathrm{b}}$ Sera submitted to a commercial anti-gE antibody ELISA test (Bovine Rhinotracheitis Virus gE Antibody Test - IDEXX - the Netherlands); ${ }^{\mathrm{c}}$ Sample negative in VN assay at its lower dilution (1:2); ${ }^{\mathrm{d}}$ Samples negative in the anti-gE ELISA test; ${ }^{\mathrm{e}}$ Samples positives in the anti-gE ELISA test; ${ }^{\mathrm{f}}$ The average of serology results is expressed as geometric mean titers (GMT - $\log 2$ ).
}

and size of pustules in the nasal mucosa. Two of the control animals presented coalescent pustules covering most of the nasal mucosa and the other two controls presented localized coalescent pustules. In contrast, the vaccinated group presented only serous nasal discharge, did not show ocular discharge or conjunctivitis and developed few, small and localized pustules in the nasal mucosa. The overall daily clinical score developed by control and vaccinated groups are shown in Figure 3.

All vaccinated animals remained negative to $\mathrm{gE}$ antibodies up to the day of challenge (day $47 \mathrm{pv}$ ), seroconverting to gE thereafter. At day 30pc all vaccinated and control animals were positive in the gE ELISA, remaining positive up to day $90 \mathrm{pc}$ (Table 4).

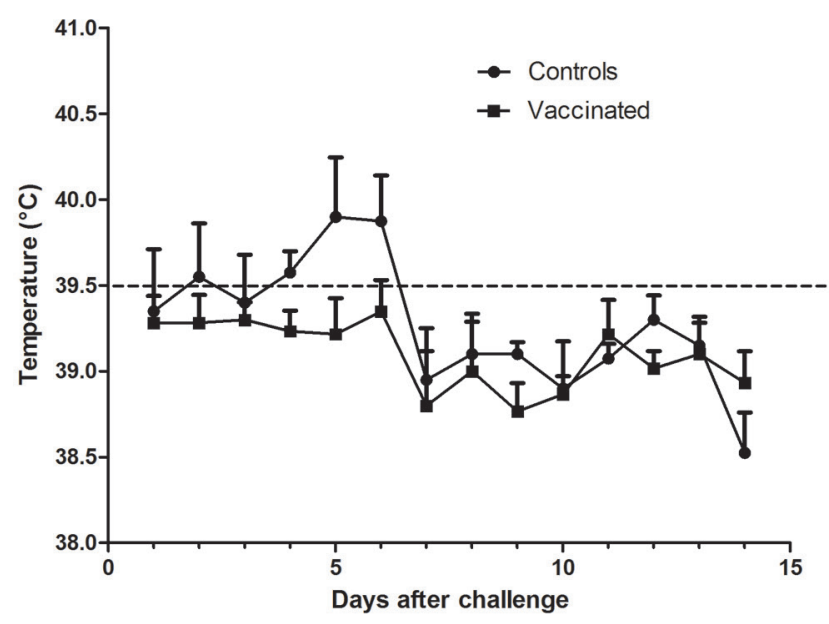

Fig.1. Body temperature of calves of the challenge test. Six animals were vaccinated with a BoHV-1gE $\Delta$ virus and 47 days later were challenged with a heterologous virulent BoHV-1 strain. Four calves were kept as controls. Dotted line marks the threshold for fever. Bars represent the mean standard error.

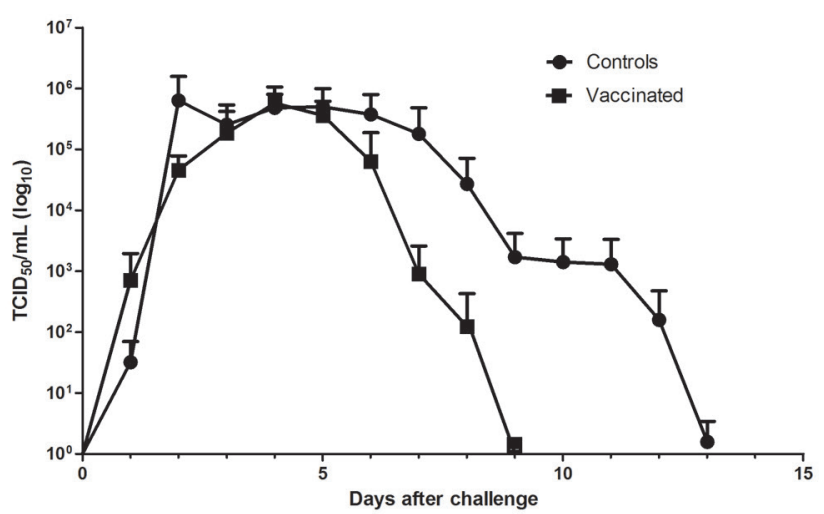

Fig.2. Virus shedding in nasal swabs collected from calves of the challenge test. Mean virus titers for each group (vaccinated, controls) expressed in $\log _{10} \mathrm{TCID}_{50} / \mathrm{ml}$. Six animals were vaccinated with a BoHV-1gE $\Delta$ virus and 47 days later were challenged with a heterologous virulent BoHV-1 strain. Four calves were kept as controls. Bars represent the mean standard error.

Taken together these results showed that immunization of calves with live BoHV-1gE $\Delta$ conferred satisfactory protection against challenge with a heterologous, virulent BoHV-1 strain. Protection was demonstrated by reduction in virus shedding (magnitude and duration) and significant reduction in the intensity and duration of nasal and systemic signs (fever) in vaccinated animals.

\section{DISCUSSION}

Our results showed that the recombinant BoHV-1gE $\Delta$ - a candidate vaccine strain constructed out of a Brazilian BoHV-1 isolate - is safe and immunogenic for calves and, as expected, induces a serological response that can be differentiated from that induced by wild type virus. Highly susceptible calves inoculated IM with a viral dose higher than 10 to 


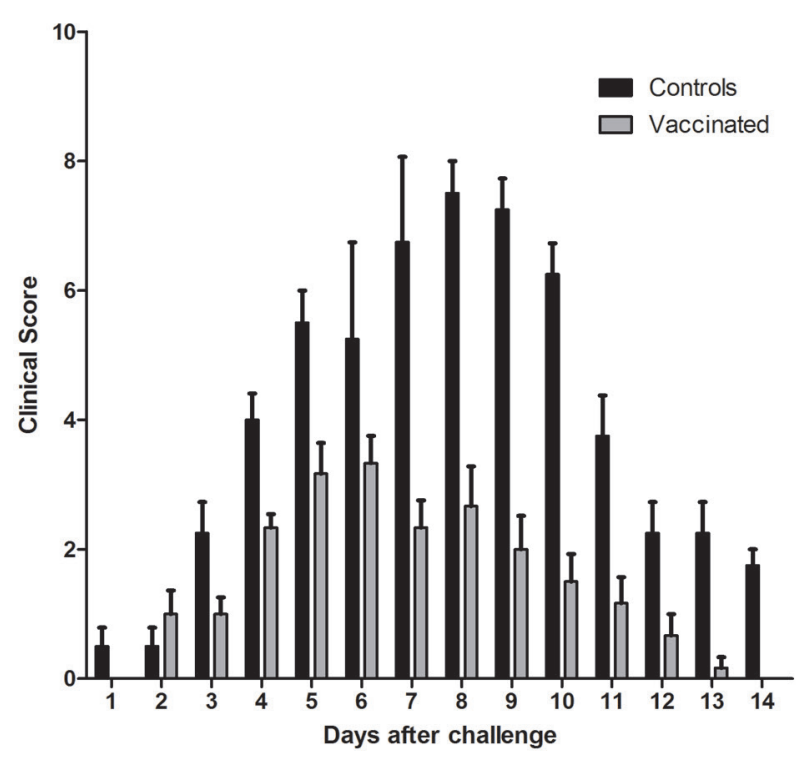

Fig.3. Clinical score of the challenge test. Six calves were vaccinated with BoHV-1gE $\Delta$ and 47 days later were challenged with a heterologous virulent BoHV-1 strain. Four calves were kept as controls. Bars represent the mean standard error.

100-times an usual vaccine dose remained healthy, did not shed virus following virus inoculation nor after Dx treatment. Immunization of calves with live virus or with inactivated, adjuvanted virus preparations resulted in a VN response of adequate magnitude. In addition, vaccination-challenge experiments demonstrated that the recombinant was able to induce satisfactory protection upon stringent challenge with a heterologous BoHV-1 strain, as measured by reduction in viral shedding and clinical protection. These results are promising towards the use of this recombinant in vaccine preparations. Additional safety tests in pregnant cows, largescale immunization in field conditions and evaluation of the duration of immunity are currently underway to confirm the adequacy of this recombinant for vaccine use.

DIVA vaccines - most of them based on gE deletion have long been used for the control/prevention of BoHV-1 infection and disease in several European countries (Van Drunen Littel-Van den Hurk 2006) and have been gradually introduced in other continents. In South America, a number of gE-deleted BoHV-1 and BoHV-5 recombinants have been constructed and proposed as candidate vaccine strains (Franco et al. 2002a, Brum et al. 2010b, Romera et al. 2014). Nonetheless, no such vaccine is yet commercially available in South American countries (Anziliero et al. 2015). The reasons for the delay in making the BoHV1 recombinants (Franco et al. 2002a, Romera et al. 2014) commercially available are unknown. For this reason, we decided to construct and to evaluate another BoHV-1 gE-deleted recombinant.

As the recombinant BoHV-1gE $\Delta$ is intended to be used either in modified live vaccine (MLV) or in inactivated vaccines, a safety would be required to assess its inocuity. The safety test, performed in highly susceptible young calves and using such a high virus dose (as recommended by the Euro- pean Pharmacopea for live viral vaccines) confirmed the safety of the recombinant. Upon IM inoculation, no infectious virus was recovered from nasal secretions nor seroconversion of sentinel calves was observed. In this sense, a number of studies have demonstrated that gE deletion contributes for BoHV-1 attenuation and, thus, reinforces the choice for gE deletion as an antigenic marker for BHV-1 vaccines (Kaashoek et al. 1994, 1998, Van Engelenburg et al. 1994, Mars et al. 2000, Franco et al. 2002b, Romera et al. 2014). On the other hand, the serological response developed by inoculated calves demonstrated that proper vaccine virus replication did ensue upon IM inoculation in these calves.

In addition to the safety during acute infection, the recombinant was not excreted upon Dx treatment, confirming previous findings that gE-deleted BoHV-1 recombinants are deficient in reactivation and/or in shedding upon corticosteroid treatment (Kaashoek et al. 1998, Mars et al. 2000, Brum et al. 2009, Chowdhury et al. 2010). Regardless the reasons for the lack in virus shedding upon Dx treatment (defficient establishment of latency, deficient reactivation or deficient anterograde transport), this is a highly desirable phenotype in a herpesvirus candidate vaccine strain.

Glicoprotein E-deleted BoHV-1 mutants usually produce smaller plaques in cell culture than wt virus and show a reduced immunogenicity in vivo (Kaashoek et al. 1994, Chowdhury et al. 1999). In our experiments, however, immunization of calves with the recombinant induced a VN response equivalent to that induced by the parental virus (Table 2). Nonetheless, as the protection induced by live herpesvirus vaccines also rely upon the cellular response, it would be interesting to assess whether the cellular response induced by gE-deleted virus would differ from that induced by wt virus (Romera et al. 2014).

The immunogenicity of the recombinant was also demonstrated in inactivated vaccine preparations. In this assay, the VN response in calves immunized with inactivated virus plus Montanide ${ }^{\mathrm{TM}}$ gel 1 was significantly higher than the VN response to virus combined with aluminum hydroxide (Table 3). As the licensing of recombinant live vaccines for livestock is a time-consuming and laborious process in Brazil, this recombinant would probably be used first in inactivated formulations. Regardless, in both cases, the serological response induced by vaccination could be differentiated from that induced by parental virus by the use of a commercial ELISA (Table 2 and 3). In addition, Anziliero et al. (2015) showed that the VN response induced by inactivated, aluminum adjuvanted Brazilian commercial vaccines was comparable, yet generally lower, than that observed in this study.

The vaccination-challenge experiments demonstrated a satisfactory degree of protection conferred by vaccination with live recombinant virus, as demonstrated by reduction in virus shedding and clinical protection after challenge.. It should be emphasized that we performed a highly stringent challenge, using a high dose of a highly virulent virus (Spilki et al. 2004). Unfortunately, no BoHV-1 vaccine has been shown to completely abolish virus shedding upon challenge, raising a concern about possible selection of escape mutants. Regardless, vaccinated animals shed the 
challenge virus in much lower titers and for a shorter period of time (in most of the time). These animals also developed only mild signs of nasal/respiratory disease and recovered faster than the controls (Fig.2 and 3). In contrast, the animals from the control group showed more severe clinical signs, most of then correlated with the presence of mucopurulent nasal discharge and the number and size of the pustules in the nasal mucosa. It is reasonable to speculate that, under natural conditions, in which challenge would be likely significantly lower/weaker, the vaccine would confer a higher degree of protection.

Bovine herpesvirus 5 (BoHV-5) is a neuropathogenic virus, closely related to BoHV-1 and highly prevalent in South American countries (Del Medico Zajac et al. 2010). The high antigenic similarity and extensive cross-neutralization between BoHV-1 and 5 has led to the concept that proper immunization with either virus would confer cross protection (Del Medico Zajac et al. 2010, Anziliero et al. 2011). Thus, an adequate BoHV-1 vaccine accompanied by a reliable vaccination program would probably confer protection to both viruses in areas where they co-circulate. Regardless these hypothetical considerations, it should be advisable to test this vaccine against BoHV-5 challenge to generate confirmatory data that would allow confirmation of this hypothesis.

Regarding to safety, vaccine tests involving cows in different stages of pregnancy need to be performed to demonstrate that the vaccine strain is safe to be used in these animals. Likewise, vaccination-challenge experiments after immunization with an inactivated virus formulation still have to be performed in order to ensure the safety and efficacy of this vaccine candidate.

In summary, our experiments demonstrated that the recombinant BoHV-1gE $\Delta$ virus is safe (was not shed by inoculated animals nor transmitted to sentinel animals; did not reactivate infection upon Dx treatment and is immunogenic for calves both in live and inactivated preparations. Vaccination-challenge tests demonstrated that immunization of calves with the recombinant conferred partial virological and clinical protection upon challenge. Further, both live and inactivated virus preparations induced a serological response that could be differentiated from that induced by wt virus. Thus, the recombinant BoHV-1gE $\Delta$ presents properties that candidates it as a vaccine strain, upon additional experiments to confirm its safety and immunogenicity. The availability of a commercial gE-ELISA test for serological differentiation would favor its use as a vaccine strain in control/eradication programs of BoHV-1/5 infection in Brazil.

Acknowledgements.- This article is part of the Doctoral thesis of the first author. M. Weiss is recipient of doctoral scholarships from CNPq (National Counsel of Technological and Scientific Development, Protocol number 142148/2011-3). E.F. Flores and R. Weiblen are recipients of CNPq scholarships. The project was funded by PRONEX, FAPERGS and CNPq.

\section{REFERENCES}

Anziliero D., Santos C.M., Brum M.C., Weiblen R., Chowdhury S.I. \& Flores E.F. 2011. A recombinant bovine herpesvirus 5 defective in thymidine kinase and glycoprotein $\mathrm{E}$ is immunogenic for calves and confers protection upon homologous challenge and BoHV-1 challenge. Vet. Microbiol. 154:14-22.
Anziliero D., Martins M., Weiss M., Monteiro F.L., Ataide C.F., Weiblen R. \& Flores E.F. 2015. Serological response to bovine herpesvírus 1 and 5 and bovine viral diarrea virus induced by comercial vaccines. Ciência Rural 45:58-63.

Brum M.C., Coats C., Sangena R.B., Doster A., Jones C. \& Chowdhury S.I. 2009. Bovine herpesvirus type 1 (BoHV-1) anterograde neuronal transport from trigeminal ganglia to nose and eye requires glycoprotein E. J. Neurovirol. 15:196-201.

Brum M.C.S., Caron L., Chowdhury S.I., Weiblen R. \& Flores E.F. 2010a. Immunogenicity of an inactivated bovine herpesvirus type 5 strain defective in thymidine kinase and glycoprotein E. Pesq. Vet. Bras. 30:57-62.

Brum M.C.S., Weiblen R., Flores E.F. \& Chowdhury S.I. 2010b. Construction and growth properties of bovine herpesvirus type 5 recombinants defective in the glycoprotein E or thymidine kinase gene or both. Braz. J. Med. Biol. Res. 43:217-224.

Chowdhury S.I., Ross C.S., Lee B.J., Hall V. \& Chu H.J. 1999. Construction and characterization of a glycoprotein E gene-deleted bovine herpesvirus type 1 recombinant. Am. J. Vet. Res. 60:227-232.

Chowdhury S.I., Coats J., Neis R.A., Navarro S.M., Paulsen D.B. \& Feng J.M. 2010. A bovine herpesvirus type 1 mutant virus with truncated glycoprotein E cytoplasmic tail has defective anterograde neuronal transport in rabbit dorsal root ganglia primary neuronal cultures in a microfluidic chamber system. J. Neurovirol. 16:457-465.

Del Medico Zajac M.P., Ladelfa M.F., Kotsias F., Muylkens B., Thiry J., Thiry E. \& Romera S.A. 2010. Biology of bovine herpesvirus 5. Vet. J. 184:138145.

Franco A.C., Rijsewijk F.A.M., Flores E.F., Weiblen R. \& Roehe P.M. 2002a. Construction and characterization of a glycoprotein $\mathrm{E}$ deletion mutant of bovine herpesvirus type 1.2 strain isolated in Brazil. Braz. J. Microbiol. 33:274-278.

Franco A.C., Spilki F.R., Esteves P.A., De Lima M., Weiblen R., Flores E.F., Rijsewijk F.A.M. \& Roehe P.M. 2002b. A Brazilian glycoprotein E-negative bovine herpesvirus type 1.2a (BHV-1.2a) mutant is attenuated for cattle and induces protection against wild-type virus challenge. Pesq. Vet. Bras. 22:135-140.

Kaashoek M.J., Moerman A., Madic J., Rijsewijk F.A.M., Quak J., Gielkens A.L.J. \& Van Oirschot J.T. 1994. A conventionally attenuated glycoprotein E-negative strain of Bovine Herpesvirus type- 1 is an efficacious and safe vaccine. Vaccine 12:439-444.

Kaashoek M.J., Moerman A., Madic J., Weerdmeester K., Maris-Veldhuis M., Rijsewijk F.A. \& Van Oirschot J.T. 1995. An inactivated vaccine based on a glycoprotein E-negative strain of bovine herpesvirus 1 induces protective immunity and allows serological differentiation. Vaccine 13:342-346.

Kaashoek M.J., Rijsewijk F.A.M., Ruuls R.C., Keil G.M., Thiry E., Pastoret P.P. \& Van Oirschot J.T. 1998. Virulence, immunogenicity and reactivation of bovine herpesvirus 1 mutants with a deletion in the gC, gG, gI, gE, or in both the gI and gE gene. Vaccine 16:802-809.

Kahrs R.F. 2001. Infectious bovine rhinotracheitis and infectious pustular vulvovaginitis, p.159-170. In: Kahrs R.F. (Ed.), Viral Diseases of Cattle. 2nd ed. Iowa State University, Ames.

Mars M.H., de Jong M.C. \& Van Oirschot J.T. 2000. A gE-negative bovine herpesvirus 1 vaccine strain is not re-excreted nor transmitted in an experimental cattle population after corticosteroid treatments. Vaccine 18:1975-1981.

Moormann R.J., De Rover T., Briaire J., Peeters B.P., Gielkens A.L. \& Van Oirschot J.T. 1990. Inactivation of the thymidine kinase gene of a gI deletion mutant of pseudorabies virus generates a safe but still highly immunogenic vaccine strain. J. Gen. Virol. 71:1591-1595.

Muylkens B., Thiry J., Kirten P., Schynts F. \& Thiry E. 2007. Bovine herpesvirus 1 infection and infectious bovine rhinotracheitis. Vet. Res. 38:181209.

Roizmann B., Desrosiers R.C., Fleckenstein B., Lopez C., Minson A.C. \& Studdert M.J. 1992. The family Herpesviridae: an update. The Herpesvirus Study Group of the International Committee on Taxonomy of Viruses. Arch. Virol. 123:425-449.

Romera S.A., Puntel M., Quattrocchi V., Del Medico Zajac P., Zamorano P., 
Blanco Viera J., Carrilo C., Chowdhury S., Borca S. \& Sadir A.M. 2014. Protection induced by a glycoprotein E-deleted bovine herpesvirus type 1 marker strain used either as an inactivated or live attenuated vaccine in cattle. Bmc Vet. Res. 10:8.

Spilki F.R., Esteves P.A., De Lima M., Franco A.C., Chiminazzo C., Flores E.F., Weiblen R., Driemeier D. \& Roehe P.M. 2004. Comparative pathogenicity of bovine herpesvirus 1 (BHV-1) subtypes 1 (BHV-1.1) and 2a (BHV-1.2a). Pesq. Vet. Bras. 24:43-49.

Spilki F.R., Silva A.D., Batista H.B.C.R., Oliveira A.P., Winkelmann E., Franco A.C., Porciúncula J.A. \& Roehe P.M. 2005. Field evaluation of safety during gestation and horizontal spread of a recombinant differential bovine herpesvirus 1 (BoHV-1) vaccine. Pesq. Vet. Bras. 25:54-58.

Thrusfield M. 1986. Serological epidemiology, p.175-186. In: Thrusfield M. (Ed.), Veterinary Epidemiology. Butterworths, London.

Van Drunen Littel-Van den Hurk S. 2006. Rationale and perspectives on the success of vaccination against bovine herpesvirus-1. Vet. Microbiol. 113:275-282.
Van Engelenburg F.A.C., Kaashoek M.J., Rijsewijk F.A.M., Van den Burg L., Moerman A., Gielkens A.L.J. \& Van Oirschot J.T. 1994. A glycoprotein-E geletion gutant of bovine herpesvirus-1 is avirulent in calves. J. Gen. Virol. 75:2311-2318.

Van Oirschot J.T., Gielkens A.L., Moormann R.J. \& Berns A.J. 1990. Marker vaccines, virus protein-specific antibody assays and the control of Aujeszky's disease. Vet. Microbiol. 23:85-101.

Weiblen R., Kreutz L.C., Canabarro T.F., Schuch L.F. \& Rebelatto M.C. 1992. Isolation of Bovine Herpesvirus-1 from preputial swabs and semen of bulls with balanoposthitis. J. Vet. Diagn. Invest. 4:341-343.

Weiss M., Vogel F.S.F., Martins M., Weiblen R., Roehe P.M., Franco A.C. \& Flores E.F. 2010. Genital immunization of heifers with a glycoprotein E-deleted, recombinant bovine herpesvirus 1 strain confers protection upon challenge with a virulent isolate. Pesq. Vet. Bras. 30:42-50.

Weiss M., Brum M.C.S., Anziliero D., Weiblen R. \& Flores E.F. 2015. A glycoprotein $\mathrm{E}$ gene-deleted bovine herpesvirus 1 as a candidate vaccine strain. Braz. J. Med. Biol. Res. 48:843-851. 